\title{
Population structure of the Monocelis lineata (Proseriata, Monocelididae) species complex assessed by phylogenetic analysis of the mitochondrial Cytochrome c Oxidase subunit I (COI) gene
}

\author{
Daria Sanna, Tiziana Lai, Paolo Francalacci, Marco Curini-Galletti and Marco Casu \\ Dipartimento di Zoologia e Genetica Evoluzionistica, University of Sassari, Sassari, Italy.
}

\begin{abstract}
Monocelis lineata consists of a complex of sibling species, widespread in the Mediterranean and Atlantic Ocean. Previous genetic analysis placed in evidence at least four sibling species. Nevertheless, this research was not conclusive enough to fully resolve the complex or to infer the phylogeny/phylogeography of the group. We designed specific primers aiming at obtaining partial sequences of the mtDNA gene Cytochrome c Oxidase subunit I (COI) of $M$. lineata, and have identified 25 different haplotypes in 32 analyzed individuals. The dendrogram generated by Neighbor-Joining analysis confirmed the differentiation between Atlantic and Mediterranean siblings, as well as the occurrence of at least two Mediterranean sibling species. Thus validated, the method here presented appears as a valuable tool in population genetics and biodiversity surveys on the Monocelis lineata complex.
\end{abstract}

Key words: microturbellaria, sequencing, sibling species, phylogeography, phylogeny.

Received: December 10, 2008; Accepted: May 6, 2009.

Monocelis lineata (O.F. Müller, 1774) (Proseriata: Monocelididae) is a flatworm (Platyhelminthes) characterized by a comparatively "simple" morphology, and a wide distribution along the north Atlantic, Mediterranean and Black Sea coasts, occurring in brackish-water and marine habitats on any kind of substrate (Ax, 1956). Across this range, the species shows a remarkably uniform morphology, except for polymorphism related to the ocular pigment shield, which may be absent in the entire population (Curini-Galletti and Mura, 1998; Casu and Curini-Galletti, 2004). Previous molecular assays, carried out by using allozyme electrophoresis, suggested that the taxon consists of at least four sibling species, three Mediterranean species with a sharp genetic separation between brackish-water (with pigmented eyespots) and marine (unpigmented) populations, and one genetically heterogeneous, as yet unresolved "sibling" in the north Atlantic (Casu and CuriniGalletti, 2004). However, even though allozymes have proved, in past years, to be a powerful tool in discriminating sibling complexes (Manchenko and Radashevsky, 1998; Klautau et al., 1999; De Matthaeis et al., 2000; Maltagliati et al., 2000, for marine invertebrates), their application is biased by certain technical limitations (among others, the scarce reproducibility across different laboratories), which hinder routine use of the marker in biodiversity surveys. On the contrary, the sequencing of mitochondrial

Send correspondence to Marco Casu. Dipartimento di Zoologia e Genetica Evoluzionistica, University of Sassari, Via Muroni 25, 07100 Sassari, Italy. E-mail: marcasu@uniss.it.
DNA (mtDNA) gene coding for Cytochrome c Oxidase subunit I $(C O I)$ is usually performed to arrive at inferences on phylogeny and/or phylogeography in different species (Breton et al., 2003, for marine invertebrates). However, so far $C O I$ sequencing has not been applied to studies on interstitial micro-turbellarians.

We designed specific primers to amplify a partial region of $C O I$ in $M$. lineata, and validated it, while studying Mediterranean and Atlantic specimens, as a tool for population genetic studies and biodiversity surveys on the Monocelis lineata complex.

In a first step, universal primers for marine invertebrates (Folmer et al., 1994) were tested on 160 individuals from 32 populations from the northeastern Atlantic and western to eastern Mediterranean (about five specimens per sampling site) (Figure 1). We aimed at obtaining at least one suitable sequence to use as a base for designing specific primers. Specimens had been stored in $70 \%$ alcohol for a period of two to five years. DNA was extracted from the entire individual using the DNeasy ${ }^{\circledR}$ Tissue Kit (QIAGEN Inc.). PCR amplification was carried out in $25 \mu \mathrm{L}$ total volume, containing about $5 \mathrm{ng} / \mu \mathrm{L}$ of total genomic DNA, $0.4 \mu \mathrm{M}$ of each primer, $2.5 \mathrm{U}$ of Taq polymerase (Euro Taq ${ }^{\circledR}$, Euroclone), $1.25 \mathrm{mM} \mathrm{MgCl}_{2}$, in a reaction mix containing $200 \mu \mathrm{M}$ of dNTP mix and $1 \mathrm{x}$ buffer. The PCR profile consisted of an initial hot start step $\left(2 \mathrm{~min}\right.$ at $\left.94^{\circ} \mathrm{C}\right)$, and 35 cycles, each comprising denaturation for $1 \mathrm{~min}$ at $94^{\circ} \mathrm{C}$, annealing for $1 \mathrm{~min}$ at $52^{\circ} \mathrm{C}$ and extension for $1.30 \mathrm{~min}$ at $72{ }^{\circ} \mathrm{C}$, followed by a final extension for $5 \mathrm{~min}$ at $72^{\circ} \mathrm{C}$. For 
checking products obtained with universal primers, samples were electrophoresed on $2 \%$ agarose $/ 0.5 \times$ TBE gels stained with ethidium bromide $(10 \mathrm{mg} / \mathrm{mL})$, at $4 \mathrm{~V} / \mathrm{cm}$ for 20 min. Purified PCR products (ExoSAP-IT ${ }^{\circledR}$, USB Corporation,) were cycle-sequenced using the BigDye Sequencing Kit, Terminator 3.1 ${ }^{\circledR}$ (Applied Biosystems), and then analyzed on a 3100 ABI PRISM Avant ${ }^{\circledR}$ (Applied Biosystems) automated sequencer. Cycle-sequencing reactions were carried out in $10 \mu \mathrm{L}$ total volume, containing 2 to $6 \mu \mathrm{L}$ of purified PCR product and $0.32 \mu \mathrm{M}$ of the forward or the reverse primer. An initial hot start step (1 min at $96^{\circ} \mathrm{C}$ ) was followed by 35 cycles, each comprising denaturation $\left(10 \mathrm{~s}\right.$ at $\left.96^{\circ} \mathrm{C}\right)$, annealing $\left(5 \mathrm{~s}\right.$ at $\left.50^{\circ} \mathrm{C}\right)$ and extension $\left(4 \mathrm{~min}\right.$ at $\left.60{ }^{\circ} \mathrm{C}\right)$. Cycle-sequencing products were purified using the SigmaSpin Post-Reaction Clean-Up Columns ${ }^{\circledR}$ (Sigma Aldrich). Only three from the Mediterranean populations (SGo, MZo, and PPx; Figure 1) among the 160 specimens tested with universal primers showed satisfactory amplification of the target region. Sequences of $577 \mathrm{bp}, 568 \mathrm{bp}$, and $657 \mathrm{bp}$ corresponding to GenBank accession numbers EF583451, EF591057, and EU889254, respectively, were obtained. Using the software Mega 4 (Tamura et al., 2007), these sequences were aligned to those of the Platyhelminthes Nematoplana coelogynoporoides (Proseriata: Nematoplanidae) (GenBank accession number: AJ405985), and Vannuccia sp. (Proseriata: Coelogynoporidae) (GenBank accession number: AJ405986). Nucleotide alignment disclosed a high degree of identity, about $69 \%$ for $N$. coelogynoporoides and $68 \%$ for Vannuccia sp., thus point-

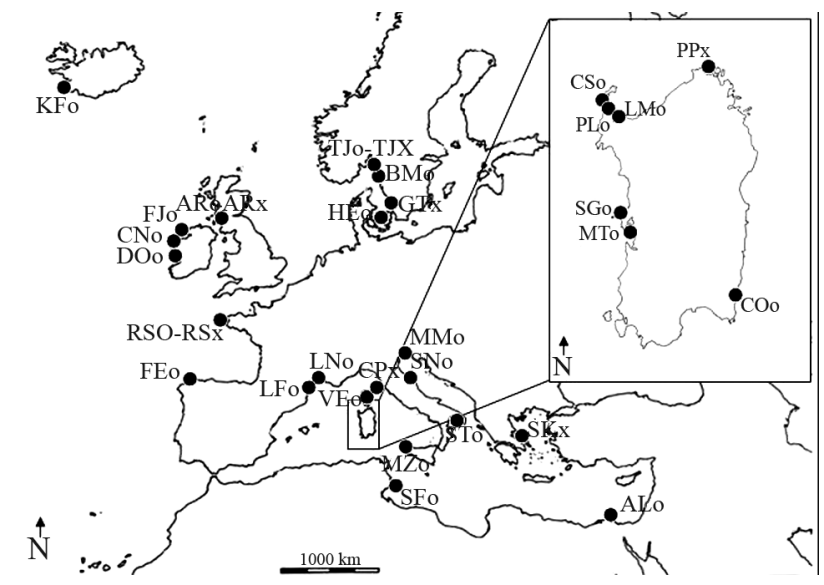

Figure 1 - Sampling sites. In the sample three-letter code, "o" indicates the presence of ocular pigment shield, " $\mathrm{x}$ " its absence. Iceland, KFo: Keflavik. Sweden, GTx: Göteborg; BMo: Bohus Malmön; TJo-TJx: Tjarnö. Denmark, HEo: Helsingør. Scotland, ARo-ARx: Ardrossan. Ireland, FJo: Fjord; DOo: Doolin; CNo: Connemara. Spain, FEo: Ferrol. France, RSo-RSx: Roscoff; LNo: Port La Nouvelle; LFo: La Franqui; VEo, Ventilegne. Italy, CSo: Stagno di Casaraccio; PLo: Stagno di Pilo; LMo: Porto Torres; SGo: Santa Giusta; MTo: Stagno di Mistras; PPx: Porto Pozzo; COo: Stagno di Colostrai; CPx: Castiglione della Pescaia; MZo: Mozia; MMo: Miramare; SNo: Senigallia; STo: Porto Cesareo. Greece, SKx: Skopelos. Tunisia, SFo: Sfax. Egypt, ALo: El-Mountazah, Alexandria. ing to the correct amplification of COI in M. lineata. Specific internal primers have been designed within the most conserved regions using Primer Premier 5.00 software (PREMIER Biosoft International, Palo Alto, CA, Table 1). The above-described PCR conditions, except for the annealing temperature at $51{ }^{\circ} \mathrm{C}$, were used for the designed primers, thus permitting amplification of a 195-199 bp fragment of the COI gene in three specimens of M. lineata. We then studied one individual from each sampling site (Figure 1) in a total of 32 specimens, in order to investigate genetic variability between and within Atlantic and Mediterranean populations.

PCR amplification with the designed primers yielded short fragments (about $200 \mathrm{bp}$ ) of the COI gene. This however does not represent a bias, for it has been demonstrated that sequences of about or less than two hundred bp may correctly show the phylogenetic/phylogeographic traits of the species (Tillier et al., 1992; Kirby and Reid, 2001, Bucklin and Allen, 2004, Hajibabaei et al., 2006).

The results obtained by using DNAsp 4.0 software (Rozas et al., 2003) revealed a low mean nucleotide value $(P i=0.21)$ and elevated mean haplotype diversity $(H d=0.97)$, distributed on 25 diverse haplotypes out of the 32 sequences analysed (GenBank accession numbers: EU889254-EU889265; $\quad$ EU889268-EU889272; EU889275-EU889276; EU889278-EU889291). The

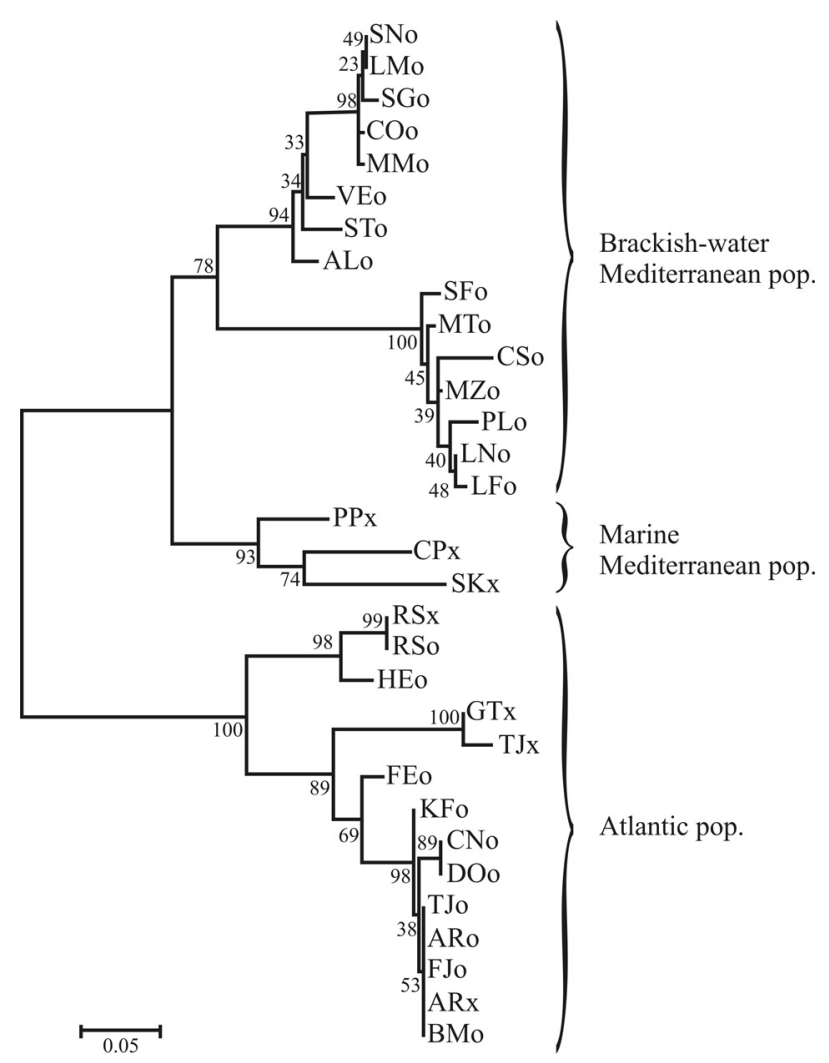

Figure 2 - MCL Neighbor-Joining dendrogram for the COI fragment of the sampled specimens of $M$. lineata. Bootstrap values are shown above the branches. The location codes are the same as in Figure 1. 
Neighbor-Joining consensus dendrogram (Figure 2), constructed by means of MEGA4 (Tamura et al., 2007) after 1,000 bootstrap replicates and by applying the Maximum composite likelihood method (MCL), placed in evidence the sharp separation between Atlantic and Mediterranean samples. Furthermore, within the Mediterranean group itself, two main clusters were observed (Figure 2), with individuals from brackish-waters (with the ocular pigment shield) and marine waters (without the ocular pigment shield), respectively. Main nodes were supported by bootstraps higher than $78 \%$ (Figure 2). Although preliminary, these findings, consistent with previous allozyme data (Casu and Curini-Galletti, 2004) showing conspicuous ge- netic differentiation between Atlantic and Mediterranean, and among Mediterranean populations themselves, further support the occurrence of a M. lineata sibling species complex.

In this context, the newly designed primers can be adequately used to obtain sequences from individuals of $M$. lineata, with high haplotypic diversity and a low level of nucleotide variability. Furthermore, the high reproducibility of the technique allows for increasing the number of individuals/populations over time. The primers here reported may thus be confidently used to resolve the complex of sibling species in $M$. lineata, and to depict phylogeographic patterns within each sibling, on both a re-

Table 1 - COI primer sequence, GenBank accession number and size of the sequences obtained for each sample of Monocelis lineata analysed.

\begin{tabular}{|c|c|c|c|c|}
\hline Locus & Primer sequences $\left(5^{\prime}-3^{\prime}\right)$ & GenBank accession $n$. & Size (bp) & Sample \\
\hline & & EU889255 & 195 & ALo \\
\hline & & EU889256 & 198 & $\mathrm{COo}$ \\
\hline & & EU889257 & 198 & SGo \\
\hline & & EU889258 & 198 & STo \\
\hline & & EU889259 & 198 & MMo \\
\hline & & EU889260 & 199 & MZo \\
\hline & & EU889261 & 198 & CSo \\
\hline & & EU889262 & 198 & LNo \\
\hline & & EU889263 & 198 & MTo \\
\hline & & EU889264 & 198 & PLo \\
\hline & & EU889265 & 198 & PPx \\
\hline & & EU889268 & 198 & $\mathrm{CPx}$ \\
\hline & & EU889269 & 198 & SKx \\
\hline & & EU889270 & 198 & VEo \\
\hline & & EU889271 & 198 & SNo \\
\hline \multirow[t]{17}{*}{ COI } & \multirow{17}{*}{$\begin{array}{l}\text { L: GTAATGCCDGTDCTTTTTGGAGG } \\
\text { H: CTHACCCCWGCCAAATGTAAA }\end{array}$} & EU889272 & 198 & LMo \\
\hline & & EU889275 & 198 & SFo \\
\hline & & EU889276 & 198 & LFo \\
\hline & & EU889278 & 195 & CNo \\
\hline & & EU889279 & 195 & DOo \\
\hline & & EU889280 & 195 & HEo \\
\hline & & EU889281 & 195 & FEo \\
\hline & & EU889282 & 195 & RSx \\
\hline & & EU889283 & 195 & RSo \\
\hline & & EU889284 & 195 & GTx \\
\hline & & EU889285 & 195 & ARo \\
\hline & & EU889286 & 195 & ARx \\
\hline & & EU889287 & 195 & FJo \\
\hline & & EU889288 & 195 & KFo \\
\hline & & EU889289 & 195 & BMo \\
\hline & & EU889290 & 195 & TJo \\
\hline & & EU889291 & 198 & $\mathrm{TJx}$ \\
\hline
\end{tabular}

L, light chain; $\mathrm{H}$, heavy chain. 
gional and local scale. Indeed, $C O I$ has been routinely used to successfully distinguish cryptic species in different "simple" organisms, e.g. Anisakid nematodes (Hu et al., 2001; Cross et al., 2006; Derycke et al., 2007).

Furthermore, the problems for non-specialists concerning the correct identification of minute mesopsammic organisms have always been a hindrance in the use of the meiofauna in ecological surveys and in assessing the actual extent of local biodiversity (Kennedy and Jacoby, 1999). Therefore, in the light of the present trend for reducing taxonomic expertise (the so-called taxonomic impediment, Boero, 2001), the finding of suitable primers for COI may be an invaluable contribution for future researches. Indeed, DNA barcoding (for a review, see Moritz and Cicero, 2004) by means of $\mathrm{COI}$ sequencing has been suggested as a promising tool to assess the actual level of marine biodiversity.

\section{Acknowledgments}

The research benefited from a grant by the Italian Ministry of Research (MIUR PRIN-2007 "Approccio integrato all'identificazione dei Proseriati”.

\section{References}

Ax P (1956) Les turbellariès des étangs côtiers du littoral méditerranéen de la France méridionale. Vie Milieu 5:1-215.

Boero F (2001) Light after dark: The partnership for enhancing expertise in taxonomy. Trends Ecol Evol 16:266.

Breton S, Dufresne F, Desrosiers G and Blier PU (2003) Population structure of two northern hemisphere polychaetes, Neanthes virens and Hediste diversicolor (Nereididae), with different life-history traits. Mar Biol 142:707-715.

Bucklin A and Allen LD (2004) MtDNA sequencing from zooplankton after long-term preservation in buffered formalin. Mol Phylogenet Evol 30:879-882.

Casu M and Curini-Galletti M (2004) Sibling species in interstitial flatworms: A case study using Monocelis lineata (Proseriata, Monocelididae). Mar Biol 145:669-679.

Cross MA, Collins C, Campbell N, Watts PC, Chubb JC, Cunningham CO, Hatfield EMC and MacKenzie K (2006) Levels of intra-host and temporal sequence variation in a large CO1 sub-units from Anisakis simplex sensu stricto (Rudolphi 1809) (Nematoda, Anisakisdae): Implications for fisheries management. Mar Biol 151:695-702.

Curini-Galletti M and Mura F (1998) Two species of the genus Monocelis Ehrenberg, 1831 (Platyhelminthes, Proseriata) from Mediterranean, with description of Monocelis lineata (O.F. Müller, 1774). Ital J Zool 65:207-217.

De Matthaeis E, Davolos D, Cobolli M and Ketmaier V (2000) Isolation by distance in equilibrium and nonequilibrium populations of four talitrid species in the Mediterranean sea. Evolution 54:1606-1613.

Derycke S, Backeljau T, Vlaeminck C, Vierstraete A, Vanfletern J, Vincx M and Moens T (2007) Spatiotemporal analysis of population genetic structure in Geomonhystera disjuncta (Nematoda, Monhysteridae) reveals high levels of molecular diversity. Mar Biol 151:1799-1812.

Folmer O, Black M, Hoeh W, Lutz R and Vrijenhoek R (1994) DNA primers for amplification of mitochondrial Cytochrome c oxidase subunit I from diverse metazoan invertebrates. Mol Mar Biol Biotechnol 3:294-299.

Hajibabaei M, Smith MA, Janzen DH, Rodriguez JJ, Whitfield JB and Hebert PDN (2006) A minimalist barcode can identify a specimen whose DNA is degraded. Mol Ecol Notes 6:959964.

Hu M, D'Amelio S, Zhu X, Paggi L and Gasser R (2001) Mutation scanning for sequence variation in three mitochondrial DNA regions for members of the Contracaecum osculatum (Nematoda, Ascaridoidea) complex. Electrophoresis 22:1069-1075.

Kennedy AD and Jacoby CA (1999) Biological indicators of marine environmental health: Meiofauna, a neglected benthic component? Environ Monit Assess 54:47-68.

Kirby RR and Reid PC (2001) PCR from the CPR offers a historical perspective on marine population ecology. J Mar Biol Ass UK 81:539-540.

Klautau M, Russo CAM, Lazoski C, Boury-Esnault N, Thorpe JP and Solé-Cava A (1999) Does cosmopolitanism result from overconservative systematics? A case study using the marine sponge Condrilla nucula. Evolution 53:1414-1422.

Maltagliati F, Peru AP, Casu M, Rossi F, Lardicci C, CuriniGalletti M and Castelli A (2000) Is Syllis gracilis (Polychaeta, Syllidae) a species complex? An allozyme perspective. Mar Biol 136:871-879.

Manchenko GP and Radashevsky VI (1998) Genetic evidence for two sibling species within Polydora cf. ciliata (Polychaeta, Spionidae) from the Sea of Japan. Mar Biol 131:489-495.

Moritz C and Cicero C (2004) DNA barcoding: Promise and pitfalls. PloS Biol 2:28-30.

Rozas J, Sánchez-DelBarrio JC, Messeguer X and Rozas R (2003) DnaSP, DNA polymorphism analyses by the coalescent and other methods. Bioinformatics 19:2496-2497.

Tamura K, Dudley J, Nei M and Kumar S (2007) MEGA4: Molecular Evolutionary Genetics Analysis (MEGA) software v. 4.0. Mol Biol Evol 24:1596-1599.

Tillier S, Masselot M, Philippe H and Tillier A (1992) Phylogénie moléculaire des Gastropoda (Mollusca) fondée sur le séquençage partiel de l'ARN ribosomique $28 \mathrm{~S}$. CR Acad Sci Paris Ser III 314:79-85.

Associate Editor: João S. Morgante

License information: This is an open-access article distributed under the terms of the Creative Commons Attribution License, which permits unrestricted use, distribution, and reproduction in any medium, provided the original work is properly cited. 